\title{
Pharmacy intervention on antimicrobial management of critically ill patients
}

\author{
Immanuel IJO, Jeffrey FEYERHARM.
}

Received (first version): 10-Dec-2010 Accepted: 15-Jun-2011

\begin{abstract}
${ }^{*}$
Frequent, suboptimal use of antimicrobial drugs has resulted in the emergence of microbial resistance, compromised clinical outcomes and increased costs, particularly in the intensive care unit (ICU). Mounting on these challenges is the paucity of new antimicrobial agents.

Objectives: The study aims to determine the impact of prospective pharmacy-driven antimicrobial stewardship in the ICU on clinical and potential financial outcomes. The primary objectives were to determine the mean length of stay (LOS) and mortality rate in the ICU resulting from prospective pharmacy interventions on antimicrobial therapy. The secondary objective was to calculate the difference in total drug acquisition costs resulting from pharmacy infectious diseases (ID)-related interventions.

Methods: In collaboration with an infectious disease
\end{abstract} physician, the ICU pharmacy team provided prospective audit with feedback to physicians on antimicrobial therapies of 70 patients over a 4month period in a 31-bed ICU. In comparison with published data, LOS and mortality of pharmacymonitored ICU patients were recorded. Daily cost savings on antimicrobial drugs and charges for medication therapy management (MTM) services were added to calculate potential total cost savings. Pharmacy interventions focused on streamlining, dose optimization, intravenous-to-oral conversion, antimicrobial discontinuation, new recommendation and drug information consult. Antimicrobial education was featured in oral presentations and electronic newsletters for pharmacists and clinicians.

Results: The mean LOS in the ICU was 6 days, which was lower than the published reports of LOS ranging from 11 to 36 days. The morality rate of $14 \%$ was comparable to the reported range of 6 to $20 \%$ in published literature. The total drug cost difference was a negative financial outcome or loss of USD192 associated with ID-related interventions. Conclusion: In collaboration with the infectious disease physician, prospective pharmacy intervention on antimicrobial therapy in the ICU led to positive clinical outcomes and an additional drug cost expense of USD192.

Keywords: Anti-Infective Agents. Intensive Care. Pharmacy Service, Hospital. Cost-Benefit Analysis. United States.

Immanuel IJO. PharmD. Post-graduate Year 1 Pharmacy Resident. Asante Health System. Medford, OR (United States).

Jeffrey FEYERHARM. RPh. Pharmacy Manager. Asante Health System. Medford, OR (United States).

\author{
INTERVENCIÓN FARMACÉUTICA EN EL \\ MANEJO ANTIMICROBIANO DE \\ PACIENTES CRÍTICAMENTE ENFERMOS
}

\section{RESUMEN}

El frecuente uso sub-optimo de antimicrobianos ha producido la aparición de resistencias bacterianas, comprometido resultados clínicos e incrementado costes, particularmente en unidades de cuidados intensivos (UCI). Agregado a esto está ala escasez de nuevos agentes antimicrobianos.

Objetivos: Este estudio trata de determinar el impacto de un control prospectivo de antimicrobianos realizado por farmacia en la UCI sobre los posibles resultados clínicos y financieros. Los objetivos primarios fueron determinar la duración de estancia media (LOS) y la tasa de mortalidad en la UCI como consecuencia de las intervenciones prospectivas de farmacia sobre el tratamiento antimicrobiano. El objetivo secundario fue calcular la diferencia total en costes de adquisición de medicamentos resultantes de las intervenciones farmacéuticas relacionadas con las enfermedades infeccionas.

Métodos: En colaboración con un medico de enfermedades infecciosas, el equipo de farmacia de la UCI proporcionó auditoria prospectiva con retorno a los médicos sobre tratamientos antimicrobianos d 70 pacientes durante 4 meses en una UCI de 31 camas. En comparación con los datos publicados, se registró el LOS y la mortalidad de los de la UCI pacientes seguidos por farmacia. Para calcular el ahorro total posible, se sumó el ahorro en costes diarios en antimicrobianos a los costes de los servicios de manejo de la medicación (MTM). Las intervenciones farmacéuticas se centraron en aumento de eficiencia, optimización de dosis, conversión intravenosa a oral, discontinuación, nuevas recomendaciones e información sobre medicamentos. La educación antimicrobiana se realizó en presentaciones orales y newsletters electrónicos para farmacéuticos y médicos.

Resultados: La LOS media en la UCI fue de 6 días, que era menor de los informes publicados que oscilaban entre 11 y 36 días. La tasa de mortalidad del $14 \%$ al margen publicado en la literatura del 6 a $20 \%$. La diferencia del coste total de medicamentos fue un resultado financiero negativo asociado a la intervención farmacéutica o pérdida de USD192. Conclusión: En colaboración con un médico infectólogo, la intervención prospectiva de la farmacia sobre el tratamiento antimicrobiano en la UCI condujo a resultados clínicos positivos y a un coste adicional de USD192. 
Palabras clave: Agentes Anti-infecciosos. Cuidados Intensivos. Servicio de Farmacia, Hospital. Análisis Coste-Beneficio. Estados Unidos.

\section{INTRODUCTION}

Approximately one-third of a hospital's pharmacy budget is attributed to the use of antibiotics, the majority of which are used in the critical care setting. ${ }^{1}$ Although 25 to 50 percent of hospitalized patients are prescribed antibiotics, 22 to 65 percent of the drugs are inappropriately prescribed. $^{2}$ Consequently, frequent suboptimal use of antimicrobial drugs has accelerated the emergence of antimicrobial resistance, compromised clinical outcomes and increased costs. ${ }^{2,3}$ To enhance antimicrobial therapy, the study was conducted to determine the impact of pharmacy-driven antimicrobial stewardship on the clinical outcomes and potential cost benefits in the intensive care unit (ICU). The primary objectives were to determine the mean length of stay (LOS) and mortality rate in the ICU. The secondary objective was to assess total drug cost outcome associated with pharmacy interventions in the ICU.

\section{METHODS}

The interventional, prospective study involved a total of 70 patients diagnosed with active infections over a four-month period from November 2009 to February 2010 in a 31-bed medical-surgical and cardiac ICU. Patients admitted to the ICU are generally diagnosed with cardiovascular diseases, active infections, such as sepsis and pneumonia, or trauma with co-morbidities spanning from congestive heart failure to renal dysfunction. The 378-bed regional referral community hospital serves over 500,000 residents spanning nine counties of southern Oregon and northern California. The study was approved by the Investigational Review Board and the Pharmacy and Therapeutics Committee.

About two years prior to the start of the study, decentralized pharmacy services expanded to the ICU. A critical care pharmacist typically accompanied by a pharmacy intern or resident, provided ICU services by engaging in daily rounds with an intensivist-directed multidisciplinary team. The infection control medical director regularly participated in ICU rounds and collaborated with the ICU pharmacist in optimizing antimicrobial therapy. In addition to participating in emergent cardiac and trauma codes, the ICU pharmacist optimized patient care by discussing therapeutic recommendations with the intensivist and provided drug information to ICU practitioners and nurses. Regularly documented in patients' medical records and computerized pharmacy-specific software program, pharmacy interventions encompassed various disease management, including ID-related interventions, anticoagulation therapy, fall risk assessment, and pain management. Due to competing clinical priorities, including order entry responsibilities, the ICU pharmacist primarily responded to formal ID consults, such as vancomycin or aminoglycoside dosing regimens, requested by physicians. Therefore, before the initiation of the study, a standardized approach to developing antimicrobial stewardship endorsed by the Infectious Diseases Society of America (IDSA) guidelines was not routinely implemented.

During weekdays over a 10-hour period, the ICU pharmacy team, comprised of clinical pharmacists, pharmacy residents and interns, documented pharmacy interventions and provided prospective feedback to prescribers in the ICU. Prospective pharmacy interventions were communicated directly to physicians during daily morning rounds and throughout the 10-hour pharmacist shift in the ICU. To adhere to best clinical practice, the ICU pharmacy team consulted with the infectious disease physician and national guidelines.

Pharmacy interventions focused on streamlining or narrowing spectrum coverage after evaluation of positive culture results and institution-specific antibiograms; dose optimization or renal dose adjustment based on creatinine clearance and published drug dosing information from Micromedex®; antimicrobial addition to cover suspected pathogens empirically when indicated; drug substitution or discontinuation due to drug intolerance and/or therapeutic duplication; and intravenous-to-oral (IV-PO)conversion, particularly for linezolid, fluoroquinolone, metronidazole and fluconazole. To be considered for IV-PO conversion, patients must have received the drug for at least 24 hours; consumed at minimum liquid diet without reported nausea; afebrile for at least 24 hours in the absence of sepsis, meningitis or endocarditis; absence of neutropenia; and presence of documented signs and symptoms of improved clinical parameters, such as lower leukocyte count and restored respiratory rate.

To determine the mean LOS, the sum of LOS was divided by the total number of participants. Mortality rate was calculated by dividing the number of deceased patients by the total number of patients. Mean LOS and mortality rate were compared with published data to assess clinical outcomes associated with pharmacy interventions. ${ }^{3-5}$ Total drug acquisition cost differences between prescribed and pharmacy-recommended antimicrobials were determined. Statistic analysis was not employed in the study.

To complement pharmacist-initiated interventions, ID-related articles were published in monthly newsletters intended for physicians and pharmacists. Monthly initial and continuing education (CE) programs accredited by the Accreditation Council for Pharmacy Education (ACPE) in the format of PowerPoint presentations were provided to educate pharmacists about various pharmacotherapeutic topics, including IDrelated best practice guidelines. Participants of $C E$ programs were required to document attendance on a manual sign-up form. 


\section{RESULTS}

In Table 1, out of a total of 70 patients, 10 patients failed to survive in the ICU, rendering a mortality rate of 14 percent, which was comparable to the reported range of 6 to 20 percent in published literature. ${ }^{3-5}$ The mean LOS in the ICU was 6 days versus 11 to 36 days documented in previous studies. ${ }^{3-5}$

Table 1. Clinical outcomes associated with pharmacy intervention

\begin{tabular}{|l|c|c|}
\hline \multicolumn{1}{|c|}{ Parameter } & Total & $\begin{array}{c}\text { Published } \\
\text { Data }^{3,4,5}\end{array}$ \\
\cline { 1 - 2 } Total number of patients & 70 & \multicolumn{1}{|c}{} \\
\cline { 1 - 2 } Number of deceased patients & 10 & \\
\hline Mortality rate & $14 \%$ & $6-20 \%$ \\
\hline Mean length of ICU/CCU Stay & 6 days & $11-36$ \\
\hline
\end{tabular}

In Table 2, since several of the patients had more than one concurrent infection, there were 78 cases monitored by the pharmacy team. The most frequently observed primary source of infection was gram-positive bacteria in the respiratory tract, which accounted for 23 percent (18 out of 78 ) of the infections. Ranked as the second most common causative agent, gram-negative bacteria were responsible for $19 \%$ (15 out of 78 ) of the infections.

\begin{tabular}{|l|c|c|}
\hline \multicolumn{3}{|c|}{ Table 2. Frequency of infectious agents } \\
\hline $\begin{array}{c}\text { Causative agent } \\
(\mathrm{n}=78)\end{array}$ & $\begin{array}{c}\text { Primary site } \\
\text { of infection }\end{array}$ & $\mathrm{N}(\%)$ \\
\hline Gram-positive bacteria & Pulmonary & $18(23)$ \\
\hline Gram-negative bacteria & Pulmonary & $15(19)$ \\
\hline Polybacteria & Pulmonary & $7(9)$ \\
\hline Suspected H1N1 virus & Pulmonary & $4(5)$ \\
\hline Candida & Urine & $3(4)$ \\
\hline Undetermined & Pulmonary & $31(40)$ \\
\hline
\end{tabular}

In Table 3 and Figure 1, the total of 93 prospective pharmacy recommendations, including those accepted and declined by physicians, was documented. Among the various types of pharmacy recommendations, dose optimization was most prevalent, attributing to $43 \%$ (40 out of 93 interventions). Drug substitution, streamlining and drug discontinuation accounted for 17,13 , and $11 \%$, respectively. The less frequent interventions were drug addition (9\%) and IV-to-PO conversion (8\%). In Table 4, cost differences between prescribed and pharmacy-recommended drugs led to an additional pharmacy expense of USD192.

\begin{tabular}{|l|c|}
\hline \multicolumn{2}{|l|}{ Table 3. Frequency of pharmacy interventions $(\mathrm{n}=93)$} \\
\hline Description of Pharmacy Intervention & $\mathrm{N}(\%)$ \\
\hline Dose optimization & $40(43)$ \\
\hline Drug Substitution & $16(17)$ \\
\hline Streamlining & $12(13)$ \\
\hline Drug Discontinuation & $10(11)$ \\
\hline Drug Addition & $8(9)$ \\
\hline IV-PO Conversion & $7(8)$ \\
\hline
\end{tabular}

\section{DISCUSSION}

Confronted with the increasing threat of multi-drug resistance and paucity of novel antimicrobial agents, many practitioners are inclined to use broad-spectrum agents indiscriminately, a prescribing trend which contributes to the emergence of antimicrobial resistance. ${ }^{6}$ To minimize the spread of antimicrobial-resistant strains, antimicrobial stewardship involving pharmacists has been developed in numerous hospitals. $^{1,6,7}$ In a study comparing clinical outcomes and appropriateness of antimicrobial prescribing, an antimicrobial management program driven by a clinical pharmacist with support from an ID medical specialist resulted in better clinical outcomes compared to a program managed by infectious diseases (ID) fellows. ${ }^{8}$

As confirmed by previous studies, the project demonstrated potential financial and clinical outcomes associated with pharmacy-managed antimicrobial stewardship. The greatest frequency of infections was derived from gram-positive pathogens, including methicillin-resistant Staphylococcus aureus (MRSA), a finding consistent with recent reports of escalating MRSA infections among hospitals. ${ }^{9}$ In a national survey, S. aureus was also ranked as one of the top three pathogens responsible for cases of healthcareassociated infection. ${ }^{10}$ Therefore, the high incidence of gram-positive infections in the project bacteria may have afforded more opportunities for pharmacists to recommend dose optimization of anti-MRSA agents, primarily vancomycin. Since the project was conducted in the critical care units where IV administration of drugs was favored in seriously ill patients, the least frequency of intervention was expectantly IV-PO conversion.

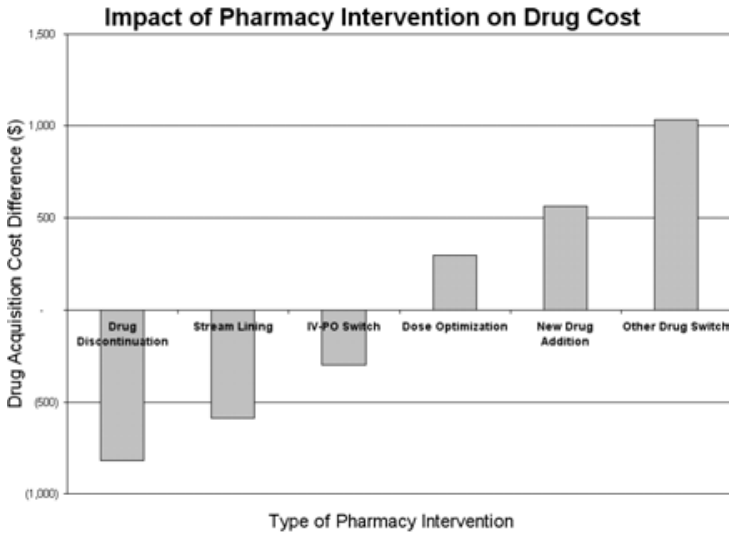

Figure 1. Types of pharmacy interventions

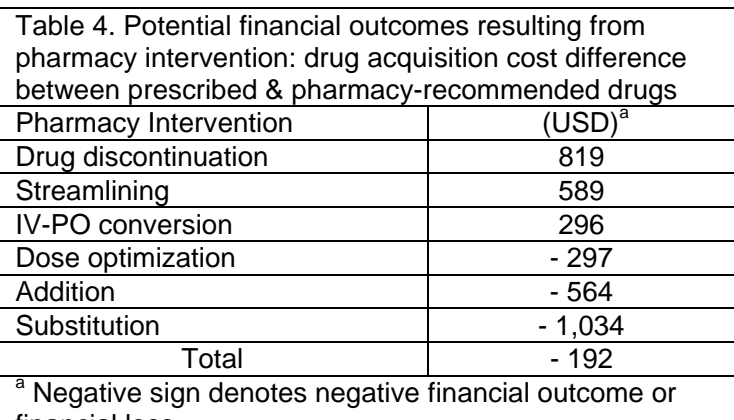

financial loss

Interestingly, cost differences in drug acquisition between prescribed versus recommended antimicrobials did not result in potential financial savings. Confounding variables, such as patients' severity of infection, underlying physiological status and comorbidities, may have led to increased use of 
antimicrobials, particularly during the winter season, which was reportedly correlated with the greatest number of visits to the emergency department. ${ }^{11}$ The study was also performed during the novel H1N1 epidemic so many patients were prescribed multiple antimicrobials. Pharmacy interventions, such as increasing the dosage of oseltamivir in critically ill or obese patients, may have led to increased drug costs. Nevertheless, the potential of reaping financial benefits from pharmacy-driven antimicrobial stewardship is substantial when other cost-related variables, such as decreased length of stay in the critical care units and improved clinical outcomes, are considered.

Limitations of the study included small sample size, lack of statistical analysis and approximation of potential cost outcomes. Since antimicrobial monitoring was performed intermittently during the weekdays due to staffing shortage, the reported number of pharmacy interventions and the potential cost savings or avoidance associated with these recommendations may not have been accurately represented. Although the ICU pharmacy team consulted with the infectious disease physician, incorporating a more robust approach towards multidisciplinary collaboration may have improved patient care. Since data prior to stewardship implementation in the ICU was not obtained, the actual impact of stewardship may not have been accurately ascertained.

\section{CONCLUSIONS}

In collaboration with the ID physician, pharmacydriven antimicrobial stewardship in the ICU resulted in positive clinical outcomes and additional drug cost expenses. Future studies may incorporate additional pertinent financial variables, such as labor cost and cost savings associated with reduced LOS, to justify stewardship development and expansion.

\section{CONFLICT OF INTEREST}

No conflicts of interest exist among the investigators in this study.

\section{References}

1. Dellit TH, Owens RC, McGowan JE Jr, Gerding DN, Weinstein RA, Burke JP, Huskins WC, Paterson DL, Fishman NO, Carpenter CF, Brennan PJ, Billeter M, Hooton TM; Infectious Diseases Society of America; Society for Healthcare Epidemiology of America. Infectious Diseases Society of America and the Society for Healthcare Epidemiology of America guidelines for developing an institutional program to enhance antimicrobial stewardship. Clin Infect Dis. 2007;44(2):159-177.

2. Ansari F, Gray K, Nathwani D, Phillips G, Ogston S, Ramsay C, Davey P. Outcomes of an intervention to improve hospital antibiotic prescribing: interrupted time series with segmented regression analysis. J Antimicrob Chemo. 2003;52(5):842-848

3. Roberts RR, Hota B, Ahmad I, Scott RD 2nd, Foster SD, Abbasi F, Schabowski S, Kampe LM, Ciavarella GG, Supino M, Naples J, Cordell R, Levy SB, Weinstein RA. Hospital and societal costs of antimicrobial-resistant infections in a Chicago teaching hospital: implications for antimicrobial stewardship. Clin Infect Dis. 2009;49(8):1175-1184.

4. MacLaren R, Bond CA, Martin SJ, Fike D. Clinical and economic outcomes of involving pharmacists in the direct care 0 critically ill patients with infections. Crit Care Med. 2008;36(12):3184-3189.

5. Arabi Y, Venkatesh S, Haddad S, Al Shimemeri A, Al Malik S. Prospective study of prolonged stay in the intensive care unit: predictors and impact of resource utlization. Int J Qual Health Care. 2002;14(5):403-410.

6. Paterson DL. Role of antimicrobial management programs in optimizing antibiotic prescribing within hospitals. Clin Infect Dis. 2006;42(Suppl 2):S90-95.

7. Kollef MH. Bench-to-bedside review: Antimicrobial utilization strategies aimed at preventing the emergence of bacterial resistance in the intensive care unit. Crit Care. 2005;9(5):459-464.

8. Gross R, Morgan AS, Kinky DE, Weiner M, Gibson GA, Fishman NO. Impact of a hospital-based antimicrobial management program on clinical and economic outcomes. Clin Infect Dis. 2001;33(3):289-295.

9. Deurenberg RH, Vink C, Kalenic S, Friedrich AW, Bruggeman CA, Stobberingh EE. Molecular evolution of methicillinresistant Staphylococcus aureus. Clin Microbiol Infect. 2007;13(3):222-235.

10. Hidron Al, Edwards JR, Patel J, Horan TC, Sievert DM, Pollock DA, Fridkin SK; National Healthcare Safety Network Team; Participating National Healthcare Safety Network Facilities. NHSN annual update: antimicrobial-resistant pathogens associated with healthcare-associated infections: annual summary of data reported to the National Healthcare Safety Network at the Centers for Disease Control and Prevention, 2006-2007. Infect Control Hosp Epidemiol 2008;29(11):996-1011.

11. National Health Statistics Report. US Department of Health and Human Services. National hospital ambulatory medical care survey: 2006 emergency department summary. 2008;7:10.

12. Zilberberg MD, Shorr AF, Kollef MH. Increase in adult Clostridium difficile-related hospitalizations and case-fatality rate, United States, 2000-2005. Emerg Infect Dis. 2009;15(2):343-344. 